\title{
Corporate Governance and Financial Performance of Insurance Companies in Nepal \\ Rajendra Maharjan*
}

\begin{abstract}
This paper aims to examine the effect of corporate governance practice on financial performance of insurance companies in Nepal. The study used board size, number of board meetings, CEO duality, Audit committee are the explanatory variables for corporate governance. Firm size and age of the firms are considered as control variables. The dependent variable performance has been measured using Return on Assets (ROA) and return on equity ROE. The study employed descriptive cum causal relational research design. All the 23 listed insurance companies are considered as the population of the study. Only 18 insurance companies (13 non-life and 5 life) is taken as sample based on availability of data representing $78.26 \%$ sample. The secondary data of profitability has been extracted from annual report of the company. The explanatory variables related to corporate governance has been collected through structured survey questionnaire. The study period accounts for the eight years from 2011 to 2018 with 141 firm year observations. Data has been analyzed using a multiple linear regression model.

The study concludes that there exists strong relationship between the corporate governance practices and firms' performance. The board meeting and audit committee were found to positively affect the financial performance of insurance companies. Board size is found to be negative but not significant. The study also concludes CEO duality has the negative impact on the performance of the insurance company. Firm with large in size with high board meeting tend to perform well. Age of the company also positively influenced on the financial performance of insurance companies in Nepal.
\end{abstract}

Key words: Book value per share, Price-earnings ratio, return on equity, dividend yield, stock price

* Mr Maharjan is currently working in Beema Samiti (Insurance Regulatory Authority of Nepal) as an Assistant Director, Kupondole rajendra.maharjan707@gmail.com ph no 9851066553, 01-5528618 


\section{Introduction}

Corporate Governance has become common interest in every sector. After the collapse of Enron and the corporate scandals that occurred in October 2001 till the present day, the investor's confidence in the market has shaken. Since then, investor, government, practitioners, academicians and regulators have growing interest and focus on the corporate governance. According to Yacuzzi (2005), corporate governance ensures that there exist policies that can encourage performance. The modern business environment poses a number of challenges that require sound decision making and appropriate corporate governance practices. For any organization to succeed in achieving good performance, it must be able to embrace conventional good corporate governance (Edwards \& Clough, 2005).

Corporate governance is primarily concerned with how effective different governance systems are in promoting long term investment and commitment amongst the various stakeholders. Corporate governance is related to the protection of shareholder's interests and has roots in the issue of separation between management and control (Tirole (2001). For Kawakami et al. (1994), corporate governance is a generic term that describes the ways in which rights hand responsibilities are shared among the various corporate participants, especially the management and the shareholders.

The concept of corporate governance stems from a number of theories that explain the concept such as the Agency theory, the stewardship theory, and resource based theory and the stakeholder theory.

The Agency theory is based upon conflicts of interest between various contracting parties such as shareholders, corporate managers and creditors. It was first proposed by Jensen \& Meckling in 1976. According to this theory, Brennan (1995) agency problems arise because of the impossibility of perfectly contracting for every possible action of an agent whose decisions affect both his own welfare and the welfare of the principal. McColgan (2001) also asserts that argues that the scope of each type of agency conflict will differ from one firm to another, as will the effectiveness of governance mechanisms in reducing them.

Under the stewardship theory, company executives protect the interests of the owners or shareholders and make decisions on their behalf with sole objective is to create and maintain a successful organization so the shareholders prosper. According to Arthurs (2003) there is no misalignment between the interests of managers and owners. Wesley (2010) individuals are not motivated by personal goals but rather by the firm interests.

The shareholder theory was originally proposed by Milton Friedman based on the premise that management is hired as the agent of the shareholders to run the company for 
their benefit, and therefore they are legally and morally obligated to serve their interests (Freeman et al. 2004).

Resource dependency theory concentrates on the role of board directors in providing access to resources needed by the firm. According to Hillman, Canella and Paetzold (2000) that directors bring resources to the firm, such as information, skills, access to key constituents such as suppliers, buyers, public policy makers, social groups as well as legitimacy.

International Association of Insurance Supervisors (2000) mentioned the good should ensure the basis for an effective corporate governance framework, the rights of shareholders and key ownership functions, equitable treatment of shareholders, role of stakeholder, disclosure and transparency and responsibility of the board.

OECD (2004) established certain principles of corporate governance, which have adopted by member countries. As per OECD, corporate governance involves a set of relationship between company's management, its board, its shareholders and other stakeholders. In context of Nepal, Company Act (2006, clause 164) address the compliance of corporate government with a director who is not involved in daily work of the company consisting of at least three members in a board. It ensures that companies running under this act bounded to make their accounting transparent. Nepal Rastra Bank and Beema Samiti had issued the directives in early 2010 for the first time.

Recently, the corporate governance of Beem Samit has been revised recently in 2018 mentioning appointment procedure, structure, roles and responsibility, qualification of the board of the companies as well as CEO. It also mention about board meeting, accountability, transparency, salary and allowance, financial reporting of the insurance companies. The insurance regulatory authority, insurance board ensuring all the insurance companies comply in the good governance.

\section{Insurance Company in Nepal}

Under the Insurance Act, 1968, Beema Samiti (Insurance Board) was established as a sole authority to regulate the insurance activities within Nepal to systematize, regulate, develop and regularize the insurance business in Nepal. Insurance Act, 1968 was repelled by new insurance Ac, 1992. A new reformed insurance act 2016 has been proposed which has yet to be get approval from Ministry of Finance.

The real expansion of the insurance industry in Nepal took place during the 1990s following the financial sector reform and liberalization of the economy by the government. The new policy gave emphasis to the involvement and growth of insurance business in the private 
sector. As a result, many companies came into the scene in the private sector including foreign. Out of 27 insurance companies majority of them 19 (70.37\%) are public limited company, 2 is government owned ( 1 non-life as Rastriya Beema company and 1 life as Rastriya Beema Sansthan), 3 foreign and rest 3 joint venture.

Insurance industry in Nepal is resilient even though the country has been going through various economic and political problems. This resilience is evidenced by the determination of the industry to survive and thrive. The local life assurance industry is which accounts for about one third of total million total premiums (life 161 million and non-life 92 million) in the insurance industry. The non-life segment has moved beyond motor and property insurance. Agriculture insurance has almost four years in practice and growing its business day by day. Micro-insurance products are launch from this year for the poor people.

Poverty and lack of awareness appear to be major constraints of insurance business in developing countries (Business Monitor, 2012). State-owned enterprises, potentially substantial users of insurance, have financial problems. Insurers have been overly dependent on traditional products and distribution channels. Moral hazard and slow claim have been significant problems. However, there are opportunities such as investment by and partnerships with South Asian insurers indicate that Nepal insurers have access to foreign capital as insurance penetration is very low.

A key success factor in the insurance business is to create continuous trust and confidence in policyholders and customers. The benefit of good corporate governance practices is to facilitate effective firm's management in the current global and dynamic environment. In addition, lack of trust that most Nepalese have on the insurance businesses due to absence of accountability and reliable service. Keeping this fact, the insurance board of Nepal has recently bought regulation in corporate governance.

\section{Statement of the Problem}

Corporate governance ensures stockholders have limited responsibility and that they are not necessarily managers. Absence of governance controls would allow managers to pursue interests that are likely to deviate from that of the corporate owners. Financial performance is part of financial management in organizations which involves the art and science of managing financial resources of an organization (Jacobs, 2001). This is an area that requires knowledge, skills and experience and whose goals include: maximizing profits. Okwee (2011) and Oskar (2012) carried out a study on corporate governance and financial performance reveals that there is strong positive correlation between corporate governance and financial performance. 
Australian Treasury (2009) conducted corporate governance and financial performance. The aim of the study was to examine the relationship of a company's adoption of the corporate governance principles and best practice as outlined by the Australian Securities Exchange and the financial performance of Australia's top listed 300 companies. The study findings revealed that companies that implemented the corporate governance principles and practices have very significant impact in the financial performance of organizations.

Otieno (2011) studied 44 commercial banks using cross sectional data the study reveals that corporate governance play an important role on bank stability, performance and bank's ability to provide liquidity in difficult market conditions. Similar finding by Liech (2011) shows that there is a significant relationship between corporate governance practices and financial performance of airlines. A study conducted by Guze (2012) on the effect of corporate governance on performance of public corporations in Kenya established that corporate governance plays a major role in determining the level of performance. Larcker and Tuna (2007) found that weak connection between corporate governance and firm performance. In this regard how the corporate governance practices affect the performance of insurance industry is the issue of the study.

The insurance industry in Nepal faces a number of governance challenges despite the tight regulatory framework that has been put in place. The Insurance regulatory authority insurance board also identified poor corporate governance as a challenge to achievement of strategic plan. In spite of the large number of works published during the past decades, there are important areas of corporate governance still unexplored especially in insurance sector in context of Nepal. Thus this research tends to contribute to this topic especially when focusing on insurance companies in developing countries like Nepal. This study will seek to provide the required knowledge that can be able to fill this gap.

The major objective of this study is to evaluate the measurement of corporate governance on the performance of insurance company in Nepal. It examines the relationship that exists between corporate governance and performance in the insurance company. Other specific objectives are;

i. To explore the relationship that exists between corporate governance and insurance company growth in Nepal.

ii. To identify the key determining factor of corporate governance in Nepalese insurance sector

iii. To encourage the insurance company to be alert as to the value and benefit of good corporate governance and best practice 
The remainder of this paper is organized as follows. Section two describes the review of literature and theoretical framework. Section three presents methodology followed by empirical results and the final section draw conclusion of the study findings.

\section{Review of Literature}

This section deals with the overview of past studies to identify the recent body of knowledge that affect corporate performance. The paper is followed by a review of past literature examining the relationship of corporate governance and firm performance. Based on the literature, hypothesis and theoretical framework has been developed.

\section{Corporate governance variables}

Corporate governance is one of the important issues for both develop and developing country likes Nepal. The study board size, board meetings, CEO duality, audit committee are used as explanatory variables. Size as measured by total assets and age of firm are also used as control variables to see its effect on the performance of insurance company in Nepal.

Silwal (2016) studied the effect of corporate governance on the performance of Nepalese non-financial firms listed in NEPSE from 2010 to 2015. ROA, ROE and Tobin's Q are the dependent variable for measuring firm performance while firm size, leverage, board size, age of the firm, and audit committee are the explanatory variables. The result conclude that corporate governance has significant impact on firms' performance. Board size, and leverage have negative and significant impact on ROA while age of the firm and audit committee have positive effect as ROE. Board size and audit committee were major the determining variable of firm performance in Tobin's $Q$.

Similarly, Pitamber (2018) analyzed the factors affecting corporate governance and effect on financial performance of Nepalese firms from 2009/10 to 2015/16. Profit margin and return on assets are dependent variables used to measure financial performance while corporate governance index, age of firms, size of assets, debt ratio, market to book ratio and ownership concentration are considered as explanatory variables. The study reveals that profit margin and return on assets of firms are positively related with age, market to book ratio and overall corporate governance index while size of assets and debt ratio have negative effect and ownership concentration has no relationship with firms' financial performance.

Aswathy and Chandramohan (2018) examined the impact of corporate governance on firm performance in Indian with 30 firms quoted in the Bombay Stock Exchange. The results of the panel data analysis show that the CG factor, namely CEO duality and board size has 
a significant negative impact on firm performance whereas board composition revealed no significant impact on firm performance. It reveals that there is a need to undertake the monitoring process to lead to superior firm performance and indicates the need for firms to separate the post of CEO and Chair in order to ensure optimal performance. The results also suggest the leverage and asset turnover to have a significant positive impact on firm performance.

Marsigalia, et al. (2019) present empirical paper aims to investigate the effect of a longterm company culture in terms of economic performance and firm value. Comparing firm longevity with the performance indicators, but also monitoring many other corporate governance or ownership indicators, on a panel dataset of the top Italian wine companies. The study reveals that larger presence of women on board, a higher average age of the directors and a higher propensity to the production of grapes. The research findings support the hypothesis that a family firm add value over the generations through generating an internal cumulative knowledge process and a strong brand image. In addition, the presence of an external CEO is positively influencing performance (the Most Trusted Advisor). Firm value increases along with the number of family members within the board, to support the family logic and the social capital theories.

\section{Board Size and firm performance}

Empirical evidence on the relationship between board size and firm performance provide mixed result. The study by Bhagat and Black (2002), found that there is no solid evidence on the relationship between board size and performance. One school of thought find that larger boards are more likely to be associated with an increase in board diversity in terms of experience, skills, expertise, and better access to market and make proper decision (Dalton and Dalton, 2005). One the other hand large boards can be less effective as too many members may create agency problems (Lipton and Lorsch, 1992, Jensen,1993, Vafeas ,2000, Hermalin and Weisbach 2003,) ). Generally, While, Ahmadu et al. (2005), Chan and Li (2008), De Andres et al. (2005) and Mustafa (2006) found that larger boards are associated with poorer performance. John \& Senbet (1998) assert that large boardrooms tend to be slow in making decisions, and hence can be an obstacle to achieving good financial performance as opposed to small board size. WOCCU report (2005) observes that a board constituted by fewer than five members, may find it difficult to adequately represent its diverse member body, just as a board more than nine members may make consensus achieving difficult and may increase logistical problems. Based on it, the study formulates the following hypothesis.

H1: there is a negative relation between board size and firm performance of the board and the value of the firms 


\section{Board meeting and firm performance}

Board meetings and attendance of the meetings are considered to be important factors through which directors obtain firm specific information and able to fulfill their monitoring role. Frequency of board meetings is considered to be an important way of improving the effectiveness of the firm (Lawler \& conger, 2009). Ntim \& Osei, (2011) conducted a study in South Africa which also suggested similar findings between the frequency of board meetings and corporate performance where boards that meet more frequently tend to generate higher financial performance. In addition, study conducted by Francis, et al. (2012) indicated that firms with poor board attendance at meetings perform significantly worse than boards which has good attendance during financial crisis. Therefore, the following hypothesis is formulated:

\section{H2: There is a positive relationship between the frequency of board meetings and firm performance.}

\section{CEO Duality and firm performance}

The Chief Executive Officer (CEO) of an organization can play an important role in creating the value for shareholders. A single person holding both the Chairman and $\mathrm{CEO}$ role improves the value of a firm as the agency cost between the two is eliminated (Alexander, Fennell and Halpern, 1993). In contrast, Carapeto, Lasfer and Machera (2005), Schmid and Zimmermann (2007) and Wan and Ong (2005) found no significant difference in the performance of companies with or without role duality. On the other side, CEO duality lead to worse performance as the board cannot remove an underperforming $\mathrm{CEO}$ and can create an agency cost if the CEO pursues his own interest at the cost of the shareholders (White and Ingrassia, 1992, Mallette (1992). Coles et al. (2001), Feng, Ghoshand and Sirmans (2005), Mustafa (2006) found negative significant relationship between CEO duality and firm performance.

The CEO duality can also cause a governance problem in an organization. Duality occurs when one individual holds the two most powerful posts of Chief Execute Officer (CEO) and Board chairman (Weir \& Laing, 2001). The separation of the two roles provides essential check and balances over management's performance. In situations where a CEO doubles as a board chairman, conflict of interest and agency costs increase therefore stifling performance (Coleman \& Osei, 2007). Based on the above discussion the study formulates the following hypothesis.

\section{H3: There is negative relationship between CEO duality and firm performance.}




\section{Audit committee}

Audit committee observes the financial reporting and maintains transparency, enhance morality, effective accounting policies, and avoid fraud, embezzlement and produce timely financial report Goldman and Barlev (1974). As per Nepalese company act, firm that has more than Rs 30 million investments have to appoint to ensure that a firm has sufficient internal controls. Internal auditors are better informed about auditing and accounting issues. When an important auditing or accounting issue arises, the audit can direct the proper level of internal audit function to address the problem promptly. Therefore, an audit committee can reduce the possibility of financial fraud (Abbott et al, 2004. Based on this, it, this study develops the following hypothesis.

H4: There is a positive association between audit committee and firm Perperformance.

\section{Firm size}

Firm size plays important role in corporate governance in firm performance. Claessens et al. (2002) confirmed that large firms have more liquidity, proper management with diversified, portfolio and thus reduce risk. Ramzan (2013) larger the firm higher the managing efficiency so there is a positive significant relationship size and firm performance. Thus, it is hypothesized that larger the firm better the corporate performance.

\section{H5: There is a positive association between firm size and firm performance.}

\section{Age}

Age refers to number of years a firm has been established and it has been widely used in different studies. Boone et al., (2007) firm age is a relevant indicator of future growth opportunities. For instance, Claessens et al. (2002) confirmed that matured firms have more liquid trading, better disclosure, well diversified, managing portfolio in reducing risk but less growth opportunity where as young firms have better growth opportunity and greater exposure to risk. Evans (1987) Borghesi et al. (2007) and conclude that older and larger firms have greater skill and experience, but less dynamic and flexible and unable to make quick response.

H6: There is a positive association between age and firm performance.

\section{Theoretical Framework}

The above discussion can be summarized in theoretical framework as given below: 


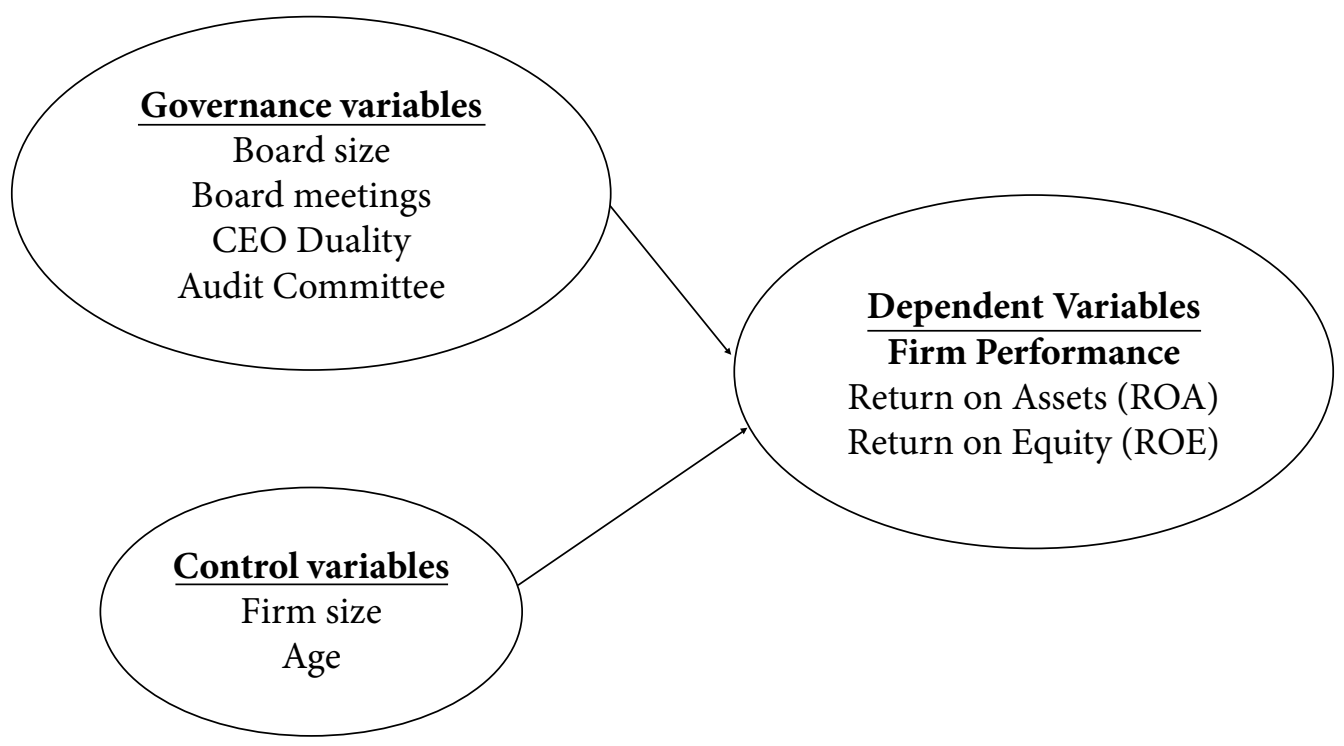

Figure 2.1

Figure 2.1 shows the conceptual framework where corporate governance issues are measured by board size, board meetings, CEO duality, audit committee, firm size and age of the firm. Return on assets (ROA) and Return on equity (ROE) are the dependent variable of firms' performance.

\section{Methodological Aspects}

According to Kothari (2004) research design is defined as framework that shows how problems under investigation will be solved. The population of this study included a census of all the insurance companies that are listed in NEPSE. The study adopted descriptive cum causal relational research design. All the 23 listed insurance companies are considered as the population of the study. Only 18 insurance companies (13 non-life and 5 life) is taken for the study representing $78.26 \%$ sample. Two non-life insurance companies are not under study as one company do not have audited report and other did not provide data on time. Out of 3 life insurance companies, two companies have still not finalized financial report and one did not provide data. Secondary data from 20011 to 2018 with $141 \mathrm{firm}$ year observations to establish the effect of corporate governance on the financial performance of insurance companies in Nepal. The study made use of secondary data to collect the information's of profitability from annual report of the company the explanatory variables related to corporate governance has been collected through structured survey questionnaire which was sent through mail that accounts for the period 2009 to 2018 with 141 firm year observations. Data has been analyzed using a multiple linear regression model. The research designed adopted in this study is descriptive cum causal relationship to see the effect of corporate governance on financial performance of insurance compa- 
nies. The study employed econometric model regression analysis to establish the relationship between corporate governance and financial performance of insurance Companies in Nepal. The following analytical model was used in analyzing the relationship between the dependent and independent variables:

\section{Model specifications}

Insurance Performance $=\mathrm{f}$ (CG variables, Control variables). More specifically,

Insurance performance $=\alpha 0+\alpha 1 \mathrm{BS}+\alpha 2 \mathrm{BM}+\alpha 3 \mathrm{CEODUA}+\alpha 4 \mathrm{AC}+\alpha 5 \mathrm{FS}+\alpha 6 \mathrm{Age}+\mathrm{ei} \ldots$ (i)

Where,

The insurance company's performance as measured y ROA and ROE is taken as dependent variable as most of the literature suggests these variables are commonly used. So, this study also employed ROA and ROE as dependent variables. The variables and it's measurement are given below.

Firm Performance (Dependent Variables)

ROA=Return on Assets

ROE=Return on Equity

Independent and control variables

\section{Corporate Governance (Independent variables)}

BS=Board Size

$\mathrm{BM}=$ Board Meetings

CEODUA $=$ CEO Duality

\section{Description}

Net income/Total Assets

Net income/Total Equity

\section{Description and Measurement} No. of members in a board.

No. of board meetings held in a year CEO occupying two important position Value zero (1) for if the same person occupies the post of the Chairman and the chief execu tive and one (0) for otherwise.

No. of members in an audit com mittee.

\section{Control variables}

FS = Firm Size

Age
Value of the firm (total Assets) Log of total assets

No of years the firm has been established 


\section{Results and Discussion}

This section of the study deals with the empirical results of sample firm.

\section{Descriptive statistics analysis}

Descriptive statistics shows the number, mean, maximum, minimum and standard deviation of the variables under considerations. The results are presented in table 4.1 below.

\section{Table 4.1: Descriptive statistics for the selected variables}

The table reports the descriptive statistics comprises minimum, maximum, mean and standard deviation of the sampled 17 firms from 2011 to 2018 for 8 years. Board size refers to the number board members, board meeting means number of meeting held in a year, CEO Duality refers to the CEO holding two major position, audit committee refers to the number of independent directors, firm size refers to the total assets as log of TA, age refers to the age of the firm, ROA means to the net income scaled by total assets, ROE refers to the net income scaled by total equity.

\begin{tabular}{lrrrrr}
\hline & N & \multicolumn{1}{c}{ Minimum } & \multicolumn{1}{c}{ Maximum } & Mean & \multicolumn{1}{c}{ Std. Deviation } \\
\hline ROA (\%) & 141 & -26.46 & 61.91 & 11.1344 & 11.81802 \\
ROE (\%) & 141 & -448.08 & 507.90 & 31.9309 & 88.24481 \\
TA (Rs. 000) & 141 & 55165.07 & 21507538.00 & 1903533.7610 & 3459158.41383 \\
BS (number) & 141 & 4 & 11 & 7.11 & 1.635 \\
BM (number) & 141 & 6 & 35 & 14.99 & 6.387 \\
CEODUA (Binary) & 141 & 0 & 1 & .33 & .473 \\
AC (number) & 141 & 0 & 8 & 2.63 & 1.569 \\
Age (Years) & 141 & 1 & 69 & 15.78 & 13.870 \\
\hline
\end{tabular}

Sources: Insurance board/Annual report of respective firms.

Corporate governance variables board size, board meeting, CEO duality, Audit committee are the explanatory variables of corporate governance with asset and age are the control variables. ROA and $\mathrm{ROE}$ are the dependent variables measuring firm performance. The return on assets ranges from -26.46 percent to 61.91 percent, with the average 11 . Board size ranges from 4 members to 11 members, leading the average member to 7.11 . Board meeting ranges from 6 to 35 averaging 14.84. CEO holding two major position is 1 else 0 . Audit committee ranges from 0 to 8 . The average firm size of the sample form is $19,03,533.76$ (in 000) and average age of sampled firm is 15.78 year.

\section{Correlation Analysis}

Correlation among corporate governance and firm performance are explained in this section and presented in table 4.2. The correlation coefficients reveal the degree of 
relationship between firm performance and variables affecting firm performance of the sample firms. The value of correlation coefficient ranges from +1 to -1 . The result is summarized below.

The correlation analysis is also useful to identify whether there exist the multicollinearity problem or not. High degree of correlation between the explanatory variables produces the multicollineratiy that produce miss interpretation. Potential test of multicollinearity is tested by producing a correlation matrix (Brooks, 2002). High correlation, actually, more that 0.8 is considered as the problem of multicollinearity. Since, the correlation coefficients are generally low except with some variables. The highest correlation has been observed between age and board meeting 0.46 sot there is no problem. So all considered variables can be included in this study for further analysis.

\section{Table 4.2 Correlation Coefficient}

The table shows the bivariate person's correlation coefficient for the dependent and explanatory variables employed in this study. The sample consists of 141 firm year's observation of 18 firms from 2011 to 2018 for 8 years. Board size, board meeting, CEO Duality and audit committee, Total asset and age variable are independent variables and ROA and FOE are dependent variables.

\begin{tabular}{lllllllll}
\hline & ROA & ROE & BS & BM & CEODU & A & C & Ln_Size \\
Age
\end{tabular}

**. Correlation is significant at the 0.01 level (2-tailed). *. Correlation is significant at the 0.05 level (2-tailed).

The table 4.2 depicts that there is positive relation of explanatory variables like board meetings, audit committee, firm size and age have positive relation with Return on assets and negative relation with board size and CEO duality. Board size, board meeting and CEO duality is found to be negative with return on equity.

\section{Regression Analysis}

The study used econometric model to see the effect of corporate governance on firm performance. Uni-variate and multivariate regression model has been used in the study. Six independent variables has been regress to see the relation and causal effect on firm performance in terms of return on assets, return. 


\section{Estimated relationships between return on assets and firm specific variables}

Table 4.3 reflects the regression analysis of the effect of corporate variables on the firm performance. For this purpose, univariate and multi vitiate regression model has been employed. Model 1 to 4 is the univariate as each corporate governance variable is regress on the ROA. Model 5, 6 and 7 are multivariate regression model used to see the effect of the control variable along with considered variable to the dependent variable ROA. The result depicts that board size, CEO duality and size of firm is negatively related with ROA. Board size is found to be negative in all models which is as per the prior hypothesis but not found significant. CEO duality is found to be negative and significant at at $5 \%$ level of significant. The result indicates that CEO holding two major position influence negatively in the performance of the firm. The result is consistent with Coleman \& Osei. (2007).

\section{Table 4.3 Estimated relationships between return on assets and firm specific variables}

The table presents 18 insurance companies comprising 13 non-life and 5 life insurance company comprises 143 firm year observation. The data are from insurance board and annual report and mail from the respective sample companies. The $t$-values of each regression coefficients are provided to have the information regarding significance of the coefficients of the corporate governance variables selected in this study.

\begin{tabular}{|c|c|c|c|c|c|c|c|c|c|c|}
\hline Model & Intercept & BS & BM & CEODUA & $\mathrm{AC}$ & Lnsize & Age & $\mathrm{R} 2$ & F-value & Sig \\
\hline \multirow[t]{2}{*}{1} & 11.827 & -0.097 & & & & & & 0.02 & 0.025 & 0.874 \\
\hline & 2.644 & 0.159 & & & & & & & & \\
\hline \multirow[t]{2}{*}{2} & 6.651 & & 0.299 & & & & & 0.031 & 4.512 & 0.035 \\
\hline & 2.857 & & $2.124 * *$ & & & & & & & \\
\hline \multirow[t]{2}{*}{3} & 11.011 & & & -0.020 & & & & 0.001 & 3.031 & 0.042 \\
\hline & 9.002 & & & $1 . .875 * *$ & & & & & & \\
\hline \multirow[t]{2}{*}{4} & 12.891 & & & & 0.528 & & & 0.022 & 3.149 & 0.078 \\
\hline & 9.218 & & & & $1.774 * * *$ & & & & & \\
\hline \multirow[t]{2}{*}{5} & 35.688 & -0.172 & 0.339 & $-0 . .269$ & 0.534 & 0.465 & & 0.103 & 3.100 & 0.011 \\
\hline & 2.884 & 0.272 & $2.419 * *$ & 1.242 & $1.675 * * *$ & $2.446 * *$ & & & & \\
\hline \multirow[t]{2}{*}{6} & 8.327 & -0.269 & 0.077 & -0.976 & 0.594 & & 0.289 & 0.152 & 4.822 & .000 \\
\hline & 1.867 & 0.438 & 0.207 & 1.408 & $1.936 * * *$ & & $3.742 *$ & & & \\
\hline \multirow[t]{2}{*}{7} & 47.544 & -0.080 & 0.142 & -0.024 & 0.413 & 0.646 & 0.347 & 0.225 & 6.472 & 0.000 \\
\hline & 4.018 & 0.974 & 0.287 & $1.834 * *$ & 1.373 & $3.555 *$ & $4.566 *$ & & & \\
\hline
\end{tabular}

$t$-values are given in lower level, ${ }^{*} 1 \%$ significant level, ${ }^{* *} 5 \%$ level of significance, ${ }^{* *} 10 \%$ level of significance

Board meeting and Audit committee are found to be positive mostly at 5\% and $10 \%$ level of significance respectively. Board meeting is found to be positive in all models as per priori sign and found be significant 5 percent level only in model 2 and 5. Size and age of the firm is found to be positive which is as per the priori hypothesis. The result also indicates that firm with large in size with high number of board meeting produce better performance. Size and age are also the determining variable in firm performance in 
Nepalese insurance sector. The result is presented below in table 4.3

\section{Estimated relationships between return on equity and firm specific variables}

The table 4.4 reflects the result of effect of corporate governance variable on firm performance as measured by ROE. Board size and CEO duality is found to be negative in all models which is as per the priori hypothesis but not significant. Board meeting is found to be positive in all models but significant. Thus board size, CEO duality and board meetings does not effect in firm's earning in terms of return on equity. Audit committee is found to be positive and significant in model 4 and 7 at $1 \%$ level of significant and $10 \%$ respectively. The result indicates that audit committee can reduce the possibility of financial fraud and help to better perform. The finding is similar with Beasley et al, (2000).

Audit committee is one of the determining variables in term of return on equity for wellestablished firm. Size of the firm is found to be positive and significant at $1 \%$ level of significant which is not as per the prior hypothesis in determining return on equity of the firm. The finding is contradicted with Ramzan (2013). Age of the firm have positive influence on return on equity indicating matured firm have diversified portfolio, better disclosure and manage risk (Claessens et al, 2002).

\section{Table 4.4 Estimated relationships between return on equity and firm specific variables}

The table presents 18 insurance companies comprising 13 non life and 5 life insurance company comprises 143 firm year observation. The data are from insurance board and annual report and mail from the respective sample companies. The $t$-values of each regression coefficients are provided to have the information regarding significance of the coefficients of the corporate governance variables selected in this study.

\begin{tabular}{|c|c|c|c|c|c|c|c|c|c|c|}
\hline \multirow{2}{*}{ Model } & \multirow{2}{*}{ Intercept } & \multirow{2}{*}{ BS } & \multirow{2}{*}{ BM } & \multirow{2}{*}{ CEODA } & \multirow{2}{*}{$\mathrm{AC}$} & \multirow{2}{*}{ Lnsize } & \multirow{2}{*}{ Age } & \multicolumn{3}{|c|}{ F- } \\
\hline & & & & & & & & R2 & Value & Sig \\
\hline \multirow[t]{2}{*}{1} & 50.564 & -2.632 & & & & & & 0.020 & .331 & 0.556 \\
\hline & 1.518 & 0.576 & & & & & & & & \\
\hline \multirow[t]{2}{*}{2} & 13.312 & & 0.092 & & & & & 0.001 & 3.007 & 0.091 \\
\hline & 1.886 & & 1.886 & & & & & & & \\
\hline \multirow[t]{2}{*}{3} & 27.819 & & & -0.334 & & & & 0.009 & .610 & 0.436 \\
\hline & 3.052 & & & 0.781 & & & & & & \\
\hline \multirow[t]{2}{*}{4} & 26.772 & & & & .011 & & & 0.013 & 3.478 & 0.00 \\
\hline & 2.540 & & & & $2.691 *$ & & & & & \\
\hline \multirow[t]{2}{*}{5} & -270.424 & -2.194 & 0.046 & -6.322 & 0.302 & 53.359 & & 0.105 & 3.177 & 0.020 \\
\hline & 2.931 & 0.466 & 0.044 & 0.390 & 0.127 & $3.759 *$ & & & & \\
\hline \multirow[t]{2}{*}{6} & 55.635 & -5.732 & 1.203 & -5.132 & 2.007 & & 1.482 & 0.053 & 4.523 & 0.002 \\
\hline & 1.581 & 1.184 & 1.006 & 0.908 & 0.829 & & $2.441 *$ & & & \\
\hline \multirow[t]{2}{*}{7} & -234.581 & -3.429 & 0.946 & -9.475 & 0.668 & 47.875 & 1.049 & 0.125 & 3.197 & 0.006 \\
\hline & 2.500 & .726 & 0.816 & .586 & $2.282 * *$ & $3.317 *$ & $1.748 * * *$ & & & \\
\hline
\end{tabular}

$t$-values are given in lower level, ${ }^{*} 1 \%$ significant level, ${ }^{* *} 5 \%$ level of significance, ${ }^{* *} 10 \%$ level of significance 


\section{Conclusion}

This paper aimed at determining the effect of corporate governance on the financial performance of Nepalese insurance sector. The study used secondary data from 2011 to 2018 comprising of 18 insurance companies that include 13 non-life and 5 life insurance company of Nepal. The study used panel data and used correlational and regression analysis to see the causal effect of corporate governance variables on firm performance.

Correlation analysis indicate board meeting, audit committee, firm size and age Board size, board meeting and CEO duality is found to be negative with return on equity. The study concludes that corporate governance affects the firm performance in Nepalese insurance sector. Board meeting and audit committee have positive effect in determining the profitability of the firm. CEO duality has the negative impact on the performance of the insurance company. Board size does not have any role in determining the firm performance. Size and age of the company positively influenced the financial performance of insurance companies in Nepal.

\section{Implications of the study}

Insurance companies act as important trustees to diversified stakeholders who are not involved in running the core activities of these firms. Due to globalization and advancement in technology today's business is more complex and competitive. So, corporate governance has lot to do in making the organization more accountable, transparent and trustworthy. Keeping this fact in mind insurance board of Nepal Beema Samiti has lunch good governance directive in 2011 and recently revised to make it more market friendly as per the IAIS core principle of good governance.

The finding of the study is useful at policy level for further improvement of insurance industry in practicing good governance. The result finds that increased in the frequency of board meeting help to resolve the timely settlement of the problem and increased the efficiency of the Nepalese insurance industry. Efficient and effective internal audit committee helps to maintain the proper accounting system and reduce the chances of fraudulent. The insurance board has should ensure the financial recording is as prescribe directives. CEO duality role produces under performing and create agency problem. So, it is strongly recommended that CEO holding two major positions should not be allowed. The study found that small firm has less earning so the regulatory authority should identify the reasons behind should revise the investment scheme of the insurance company to more productive area and means.

\section{Future scope}

The study can be further carried out with inclusion of the other corporate governance variables like independent director, board composition, number of audit meeting, 
leverage, and ownership structure. Further board and CEO qualification, experience, frequency of audit meetings were not considered in the study. Firm performance can be also measured by Tobin's Q can be incorporated. Comparative corporate governance can be also carried out between life and non life insurance company.

\section{Reference}

Abbott, L. J., Parker, S., \& Peters, G. F. (2004). Audit committee characteristics and restatements. Auditing: A Journal of Practice \& Theory, 23(1), 69-87.

Alexander, J. A., Fennell, M. L., \& Halpern, M. T. (1993). Leadership instability in hospitals: The influence of board-CEO relations and organizational growth and decline. Administrative Science Quarterly, 74-99.

Arthurs, J. D., \& Busenitz, L. W. (2003). The boundaries and limitations of agency theory and stewardship theory in the venture capitalist/entrepreneur relationship. Entrepreneurship Theory and Practice, 28(2), 145-162.

Beasley, M. S., Carcello, J. V., Hermanson, D. R., \& Lapides, P. D. (2000). Fraudulent financial reporting: Consideration of industry traits and corporate governance mechanisms. Accounting Horizons, 14(4), 441-454.

Bhagat, S., \& Bolton, B. (2008). Corporate governance and firm performance. Journal of corporate finance, 14(3), 257-273.

Brennan, M. J. (1995). A Plain Man's Response to Professor Jensen, Andersen Graduate School of Management, University of California. Working Paper.

Conger, J., \& Lawler, E. E. (2009). Sharing leadership on corporate boards: A critical requirement for teamwork at the top. Marshall School of Business Working Paper No. MOR, 19-09.

Dalton, D. R., Hitt, M. A., Certo, S. T., \& Dalton, C. M. (2007). 1 the fundamental agency problem and its mitigation: independence, equity, and the market for corporate control. The academy of management annals, 1(1), 1-64.

Edwards, M., \& Clough, R. (2005). Corporate Governance and Performance. University of Canberra, Corporate Governance ARC Project, Issues Series, paper, (1).

Fama, E. F., \& Jensen, M. C. (1983). Separation of ownership and control. The journal of law and Economics, 26(2), 301-325.

Freeman, R. E., Wicks, A. C., \& Parmar, B. (2004). Stakeholder theory and "the corporate objective revisited". Organization science, 15(3), 364-369. 
Goldman, A., \& Barlev, B. (1974). The auditor-firm conflict of interests: Its implications for independence. The accounting review, 49(4), 707-718.

Guze, P. (2012). The effect of corporate governance on performance of Parastatals in Kenya. An MBA Project submitted to the University of Nairobi.

Hermalin, B. E., \& Weisbach, M. S. (1998). Endogenously chosen boards of directors and their monitoring of the CEO. American Economic Review, 96-118.

Hillman, A. J., Cannella, A. A., \& Paetzold, R. L. (2000). The resource dependence role of corporate directors: Strategic adaptation of board composition in response to environmental change. Journal of Management studies, 37(2), 235-256.

Jacos, A. (2001). Financial Management IV (FMA 401-V): Study guide 1.

Jensen, M. C. (1993). The modern industrial revolution, exit, and the failure of internal control systems. the Journal of Finance, 48(3), 831-880.

Jensen, M. C., \& Meckling, W. H. (1976). Theory of the firm: Managerial behavior, agency costs and ownership structure. Journal of financial economics, 3(4), 305-360.

John, K., \& Senbet, L. W. (1998). Corporate governance and board effectiveness. Journal of banking \& Finance, 22(4), 371-403.

Kaplan, R. S., \& Norton, D. P. (1996). Using the balanced scorecard as a strategic management system.

Kothari, C. R. (2004). Research methodology: Methods and techniques. New Age International.

Kowalewski, O. (2012). Does corporate governance determine corporate performance and dividends during financial crisis: evidence from Poland.

Kyereboah-Coleman, A., \& Osei, K. A. (2008). Outreach and profitability of microfinance institutions: the role of governance. Journal of Economic Studies, 35(3), 236-248.

Lamichhane, P. (2018). Corporate Governance and financial Performance in Nepal. NCC Journal, vol 3(1) pp. 108-120.

Liech, W. (2011). The relationship between corporate governance practices and financial performance of local airlines in Kenya. Unpublished MBA Project. University of Nairobi.

Lipton, M., \& Lorsch, J. W. (1992). A modest proposal for improved corporate governance. The business lawyer, 59-77. 
Marsigalia, B., Giovannini, R., \& Palumbo, E. (2019). CORPORATE GOVERNANCE AND FIRM VALUE: AN EMPIRICAL INVESTIGATION OF THE WINE COMPANIES. Corporate Governance: Search for the Advanced Practices, 152.

McColgan, P. (2001). Agency theory and corporate governance: a review of the literature from a UK perspective. Department of Accounting and Finance Working Paper, 6, 0203.

Mohan, A., \& Chandramohan, S. (2018). Impact of corporate governance on firm performance: empirical evidence from India. IMPACT: International Journal of Research in Humanities, Arts and Literature (IMPACT: IJRHAL) ISSN (P), 23474564 .

Ntim, C. G., \& Osei, K. A. (2011). The impact of corporate board meetings on corporate performance in South Africa. African Review of Economics and Finance, 2(2), 83-103.

Okwee, A. (2011). Corporate Governance and Financial Performance of SACCOs in Lango Subregion. Unpublished MBA Research Project, Makerere: Makerere University.

Otieno, M. F. (2012). The effect of corporate governance on financial performance of Commercial Banks in Kenya (Doctoral dissertation).

Silwal, P..P. (2016). Effects of Corporate Governance on the performance of Nepalese Firms. The International Research Journal of Management science, vol.1 (1), pp. 42-59.

Shaw, L. (2006). Overview of corporate governance issues for co-operatives. Treasury, A. (2012). Corporate governance and financial performance in an Australian context. Treasury working paper 2009-02, Government of Australia.

Vafeas, N. (1999). Board meeting frequency and firm performance. Journal of financial economics, 53(1), 113-142.

Weir, C., \& Laing, D. (2001). Governance structures, director independence and corporate performance in the UK. European Business Review, 13(2), 86-95.

Wesley, C. L. (2010). The impact of stewardship on firm performance: A family ownership and internal governance perspective. Texas A\&M University.

Yacuzzi, E. (2005). A primer on governance and performance in small-and mediumsized enterprises. Documento de Trabajo, 293. 